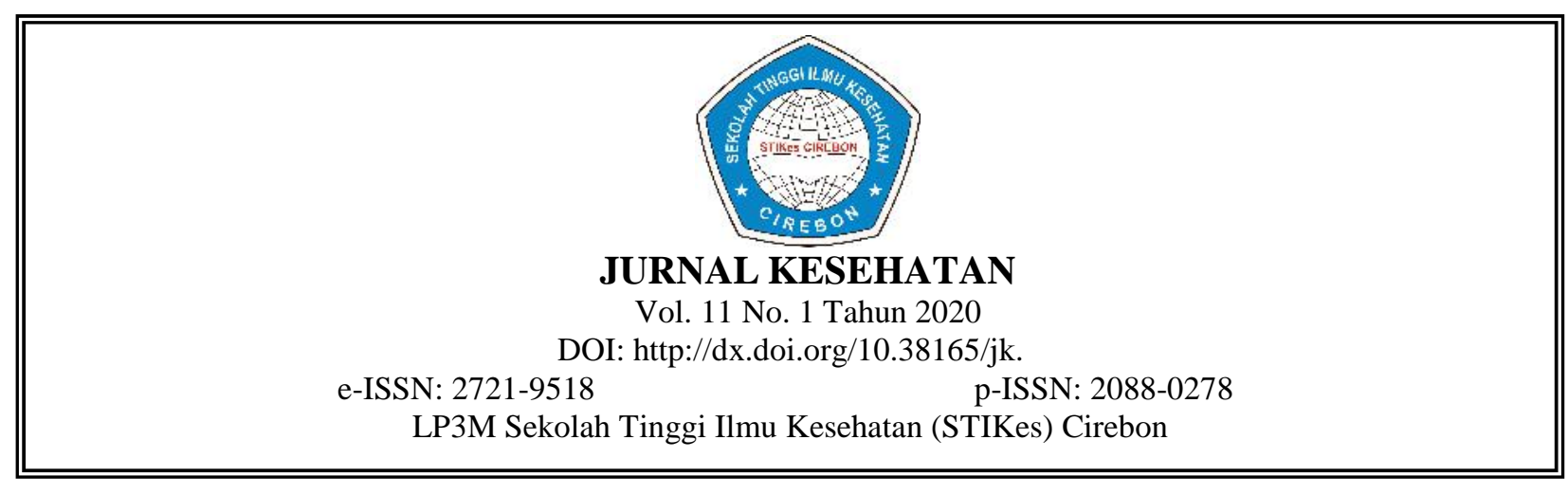

\title{
PENGARUH PENDIDIKAN KESEHATAN REPRODUKSI TERHADAP PENGETAHUAN BAHAYA SEKS BEBAS PADA SISWI KELAS VIII
}

\author{
Healthy Seventina Sirait* \\ Program Studi Ilmu Keperawatan, Sekolah Tinggi Ilmu Kesehatan Cirebon \\ healthy.seventinasirait@gmail.com \\ Asiah** \\ Program Studi Ilmu Keperawatan, Sekolah Tinggi Ilmu Kesehatan Cirebon \\ Furi Deviyani*** \\ Program Studi Ilmu Keperawatan, Sekolah Tinggi Ilmu Kesehatan Cirebon
}

\begin{abstract}
Abstrak
Pernikahan usia dini sudah menjdi permasalahan di Indramayu salah satu penyebabnya adalah seks bebas dikalangan remaja. Seks bebas adalah berhubungan intim didorong oleh hasrat seksual dengan bercumbu sampai melakukan hubungan intim tanpa adanya hubungan pernikahan. Seks bebas terjadi dikarenakan kurangnya pengetahuan tentang seksbebas. Tujuan penelitian ini adalah untuk mengetahui perubahan pengetahuan seks bebas sebelum dan sesudah dilakukan pendidikan kesehatan reproduksi.

Jenis penelitian ini menggunakan Pretest-Postest with Control Group terhadap suatu kelompok. Pengambilan sampel menggunakan purpose sampling menggunakan Taro Yamane dengan jumlah sampel sebanyak 60 responden yang dibagi menjadi kelompok intervensi dan kelompok kontrol. Instrumen penelitianyang digunakan berupa lembar kuesioner pendidikan kesehatan reproduksi. Analisis data yang digunakan untuk analisa Brivariat dengan tingkat kepercayaan $95 \%(\alpha=0,05)$.

Berdasarkan hasil uji statistik didapatkan nilai $p$ value 0,00 dengan nilai $(\alpha>0,05)$, disimpulkan bahwa ada pengaruh pendidikan kesehatan reproduksi terhadap pengetahuan bahaya seks bebas pada siswi kelas VIII Tahun 2019. Diharapkan institusi terkait dapat menggunakan pendidikan kesehatan reproduksi untuk meningkatkan pengetahuan remaja tentang bahaya seks bebas.
\end{abstract}

Kata Kunci: Pendidikan Kesehatan, Reproduksi, Pengetahuan Bahaya Seks Bebas

\begin{abstract}
Early marriage has become a problem in Indramayu. One reason is free sex among teenagers. Free sex is intercourse that is driven by sexual desire by flirting until having sex without a marriage relationship. Free sex occurs because of a lack of knowledge about it, this is due to a lack of knowledge about free sex. The purpose of this study was to determine changes in knowledge of free sex before and after reproductive health education.

This type of research uses Pretest-Posttest with Group Control of a group. Sampling using purpose sampling of the Taro Yamane formula with a total sample of 60 respondents which were divided into intervention and control groups. The research instrument used was a reproductive health education questionnaire. The research instrument used was a reproductive health education questionnaire. Data analysis used was Bivariate Analysis with a confidence level of $95 \%$ $(\alpha=0.05)$.

Based on the statistical test results obtained $p$ value 0.00 with a value $(\alpha>0.05)$, concluded that there is an influence of reproductive health education on the knowledge of the danger of free sex in class VIII students in 2019. It is expected
\end{abstract}


that related institutions can use reproductive health education to increase adolescent knowledge about the dangers of free sex.

Keywords: Health Education, Reproduction, Knowledge About the Dangers of Free Sex 


\section{PENDAHULUAN}

Fase pra pubertas disebut juga sebagai pueral. Masa dimana terjadi peralihan dari anak-anak ke remaja. Pada masa ini, terjadi perubahan-perubahan yang besar pada remaja, yaitu meningkatnya hormon seksualitas dan mulai berkembangnya organ-organ seksual serta organ-organ reproduksi remaja secara fisik, anak wanita berkembang dengan lebih cepat mereka mengalami menstruasi, pembesaran payudara, tumbuhnya jerawat, serta pelebaran pinggang dalam waktu yang singkat. ${ }^{1}$

Remaja mempunyai hasrat-hasrat yang sangat kuat dan mereka cenderung untuk memenuhi hasrat-hasrat itu semuanya tanpa membeda-bedakannya. Dari hasrat-hasrat yang ada dari tubuh mereka, hasrat seksual yang paling mendesak dan dalam hal inilah mereka menunjukkan hilangnya kontrol diri. ${ }^{2}$ Seksual mengalami perkembangan yang kadang-kadang menimbulkan masalah dan menjadi penyebab timbulnya pacaran, perkelahian, tindakan seks bebas, dan sebagainya. ${ }^{1}$

Menurut World Health Organization (WHO) mengemukakan bahwa lebih dari 700 juta perempuan di seluruh dunia saat ini menikah saat masih anak-anak, demikian data UNICEF tahun 2016. Perkawinan dini dan dipaksakan ini menjadi masalah di hampir seluruh belahan dunia, tanpa membedakan negara, kebudayaan, tradisi, agama dan etnis. Yang lebih memprihatinkan, di negaranegara berkembang bahkan satu dari tiga perempuan menikah sebelum berusia 18 tahun. ${ }^{3}$

Data statistik yang diperoleh dari Kemdikbud Indonesia, pernikahan dini pada tahun 2016 terdapat 22.000 yang di mana mereka baru berusia 10-14 tahun, melakukan pernikahan terlalu dini sangat buruk bagi kehidupan mereka hingga mereka tidak melanjutkan pendidikan, berdasarkan data dari pusat dan data statistik Indonesia angka drop outdi Indonesia untuk strata SMP pada tahun ajaran 2016-2017 sebanyak 38.702 siswa dan pada tahun ajaran 2017-2018 sebanyak 51.190 siswa. Jawa barat menyumbang angka drop outpada tahun ajaran 2016-2017 sebanyak 8.635 siswa sedangkan di tahun ajaran 2017-2018 sebanyak 9.340 siswa yang di drop out. ${ }^{4}$ Tingginya angka drop outini di karenakan banyak faktor yang salah satunya adalah faktor pernikahan usia dini dikarenakan seks bebas.

Pernikahan usia dini di Indramayu telah diperoleh data yang mengajukan dispensasi pada tahun 2018 oleh Pengadilan Agama Indramayu, di tahun 2013 tercatat sebanyak 455 pengajuan dispensasi nikah, 2014 mengalami penurunan menjadi 429, 2015 sebanyak 459 pengajuan dispensasi ${ }^{5}, 2016$ sebanyak 354 pengajuan dispensasi, di tahun 2017 sebanyak 287 pengajuan dispensasi, dan di tahun 2018 sebanyak 292 pengajuan dispensasi. ${ }^{6}$

Remaja dalam perkembangannya memerlukan lingkungan yang adaptif untuk membantu dalam pertumbuhan dan perkembangan fisik maupun dalam pencarian jati dirinya. Ada kesan dari remaja jika seks itu menyenangkan, salah satu bentuk pengungkapan rasa cinta kepada pasangannya sehingga tidak perlu ditakutkan. Hal tersebut dapat terjadi karena mendapatkan informasi yang salah mengenai seks yang berasal dari media maupun dari teman-temannya, sehingga mereka mengadopsi begitu saja norma-norma yang belum pasti kebenarannya. ${ }^{7}$

Ketika para remaja tidak mempunyai pengetahuan kesehatan reproduksi dari sumber yang benar maka tingkat terjadinya hubungan seksual akan lebih besar, maka dari itu tingkat pengetahuan kesehatan reproduksi perlu ditanamkan sejak dini kepada para remaja. ${ }^{8}$ Hal ini dikarenakan untuk menghindari dampak dari seks bebas yang di mana sebagian besar korbanya adalah wanita, karena wanita lebih rentan terhadap penyakit seksual karena perubahan hormon ekologi serta fisiologi mikroba pada vagina. $^{7}$ Pendidikan kesehatan merupakan suatu proses atau upaya untuk mempengaruhi orang lain baik individu, kelompok atau masyarakat yang berprilaku sesuai dengan nilai-nilai kesehatan.

Remaja perlu mengetahui kesehatan reproduksi agar memiliki informasi yang benar mengenai proses reproduksi serta berbagai faktor yang ada di sekitarnya. Dengan informasi yang benar diharapkan remaja memiliki sikap dan tingkah laku yang bertanggung jawab mengenai reproduksinya. ${ }^{7}$ Bertambahnya pengetahuan yang dapat di interaksikan dengan pemahaman siswa akibatnya adalah siswa akan berani mengambil sikap atas dasar pengetahuan yang diperoleh. ${ }^{10}$

Menurut Atiek Novianty (2015), tentang program pendidikan kesehatan reproduksi remaja terintegrasi terhadap peningkatan kontrol diri di Kabupaten Indramayu pada SMAN 1 Indramayu dan SMAN 1 Kandanghaur memiliki pengaruh yang signifikandengan hasil penelitian diketahui 
$(\mathrm{p}=0,041)$, peningkatan kontrol diri perilaku seksual pada remaja 54,6\% dan kelompok kontrol sebesar $48,7 \%$, ego diri $63,6 \%$ dan tempramental $65,9 \%{ }^{11}$

Data hasil studi pendahuluan yang dilakukan pada tahun 2019 di peroleh data keseluruhan siswa sebanyak 761 siswa, jenis kelamin siswa yang di dominasi oleh perempuan, siswa dengan rata-rata usia 12 tahun sampai 15 tahun.Pada tahun 2017 ada 2 siswi yang menikah, 2 Siswi mengakui dirinya penyuka sesama jenis, pada tahun 2018 baru 1 siswa yang menikah hal ini di karenakan masih baru semester awal, biasanya kasus pernikahan siswa akan meningkat jika di akhir semester 2, dan ada 1 siswi yang mengakui dirinya penyuka sesama jenis dan ada siswi yang mengaku sudah berpacaran dan sudah melakukan berpelukan, pegangan tangan, berciuman, dan bahkan ada sebagian yang sudah melakukan hubungan layaknya suami istri. Data ini merupakan data yang di dapat dari hasil wawancara dengan guru Bimbingan Konseling (BK) jika melihat dilapangan kemungkinan besar data tentang seks bebas akan lebih banyak karena berdasarkan laporan permasalahan yang disampaikan oleh guru Bimbingan Konseling (BK) sebagian besar siswi SMPN 1 Kroya memiliki pacar, dan untuk kelas 7 berdasarkan dari Guru keputrian sebagian besar sudah mengerti tentang seks (yang layaknya dilakukan oleh pasangan suami istri), mereka mengetahui hal tersebut dari situs porno yang ada di internet yang mereka akses melalui handphone mereka.

Berdasarkan data dari buku kasus dan hasil wawancara yang diperoleh dari guru Bimbingan Konseling (BK) dan guru keputrian di Sekolah Menengah Pertama Negeri (SMPN) tersebut menyatakan bahwa pendidikan kesehatan reproduksi tentang pengetahuan bahaya seks bebas belum pernah di sampaikan di Sekolah tersebut, wawancara dengan siswi tentang kesehatan reproduksi, seks, seks bebas sebagian besar mengatakan belum mengerti, padahal pendidikan ini sangatlah penting jika dilihat secara langsung dilapangan yang mungkin permasalahanya kenakalan remaja lebih banyak terjadi di lingkungan sekolah. Adapun siswi yang melihat video porno, pelecehan terhadap lawan jenis, mengkonsumsi obat-obatan terlarang, yang dapat menimbulkan kesenjangan sosial di masyarakat, sehingga dapat memungkinkan remaja terjerumus pada hubungan seksual pranikah atau kehamilan yang tidak diinginkan.

Penelitian ini dilakukan di kelas 8 karena sebagian permasalahan seksualitas tumbuh di kelas VIII pada remaja. Salah satu cara untuk pencegahan seks bebas pada remaja dengan cara pendidikan kesehatan reproduksi.Berdasarkan masalah atau fenomena di atas maka dari itu saya sebagai perawat pendidik memiliki peran dan fungsi untuk mendidik dan memberikan pengarahan bagaimana tentang hidup sehat. ${ }^{12}$ Menurut UU No. 36 Tahun 2009 pasal 1 ayat 6 yang menyatakan bahwa "Tenaga kesehatan adalah setiap orangyang mengabdikan diri dalam bidang kesehatan serta memiliki pengetahuan dan/atau ketrampilan melalui pendidikan di bidang kesehatan yang untuk memerlukan kewenangan untuk melakukan upaya kesehatan". ${ }^{3}$

Berdasarkan fenomena diatas tentang pentingnya informasi kesehatan reproduksi pada remaja, maka peneliti tertarik ingin melakukan penelitian dengan judul "Pengaruh Pendidikan Kesehatan Reproduksi pada Remaja Terhadap Pengetahuan Bahaya Seks Bebas Pada Siswi Kelas VIII”.

\section{METODE PENELITIAN}

Jenis penelitian ini adalah penelitian quasi eksperimen dengan rancangan pretest-posttest with control grup. Dimana ada dua kelompok yaitu kelompok kontrol dan kelompok eksperimen dilakukan berdasarkan acak atau random. Kemudian dilakukan pretest (01) pada kedua kelompok tersebut, dan diikuti intervensi (X) pada kelompok eksperimen. Setelah beberapa waktu dilakukan posttest (02) pada kedua kelompok tersebut. ${ }^{14}$

Variabel bebas yang diteliti adalah pendidikan kesehatan reproduksi pada remaja, dan variabel terikat adalah pengetahuan bahaya seks bebas. Populasinya yaitu seluruh siswi kelas VIII di SMPN 1 Kroya Kabupaten Indramayu berjumlah 131 siswi. Sampelnya adalah siswi kelas VIII, yang akan dilakukan pendidikan kesehatan reproduksi pada remaja terhadap pengatahuan bahaya seks bebas. Teknik pengambilan sampelmenggunakan purposive sampling dengan kriteria inklusi dan ekslusi. ${ }^{15}$ Besar sampel penelitian akan diketahui menggunakan rumus Taro Yamane. Sehingga jumlah sampel yang diambil oleh peneliti yaitu sebesar 60 sampel yang dibagi menjadi kelompok intervensi dan kelompok kontrol, peneliti membagi sampel tersebut ke seluruh kelas. 
Instrumen yang digunakan untuk mengukur pengaruh pendidikan kesehatan reproduksi pada remaja terhadap pengetahuan bahaya seks bebas diperoleh dari buku Teori dan pengukuran pengetahuan, sikap, dan perilaku manusia oleh A.Wawan dan Dwi M yang digunakan untuk pertanyaan tentang pengetahuan kesehatan reproduksi terdiri dari 25 pertanyaan dengan alternatif jawaban benar di beri nilai 1 dansalah diberi nilai 0 dimana responden memberi tanda ceklis $(\sqrt{ })$ pada jawaban yang tersedia.

Metode pengumpulan data menggunakan lembar kuesioner. Data yang dikumpulkan dikelompokkan menjadi dua macam yaitu data sebelum dan data sesudah memberikan pendidikan kesehatan. Tidak dilakukan uji validitas dan uji reliabilitas, karena mengadopsi dari buku teori dan pengukuran pengetahuan, sikap, dan perilaku manusia. Pada bagian pengetahuan 25 soal ini valid dan reliabel serta layak untuk digunakan.

Analisa bivariat menggunakan rumus Kolmogorov Smirnov karena jumlah sampelnya lebih dari 50. Nilai uji Wilcoxon Signed Rank Test pada kelompok intervensi didapatkan nilai z sebesar 4,802 dengan signifikansi sebesar 0,000 dimana kurang dari batas kritis penelitian 0,05, berdasarkan nilai p-value maka keputusan uji adalah $\mathrm{H}_{0}$ ditolak, sehingga disimpulkan terdapat pengaruh pengetahuan bahaya seks bebas sebelum dan sesudah pendidikan kesehatan pada remaja. Sedangkan pada kelompok kontrol didapatkan nilai z sebesar -1.890 dengan signifikansi sebesar 0,059 dimana lebih dari batas kritis penelitian 0,05 , berdasarkan nilai $p$-value maka keputusan uji adalah $\mathrm{H}_{0}$ ditolak, sehingga disimpulkan tidak terdapat pengaruh pengetahuan bahaya seks bebas sebelum dan sesudah pendidikan kesehatan pada remaja.

Hasil nilai Man Whitney Test pada kelompok intervensi sesudah diberikan pendidikan kesehatan dan kelompok kontrol tanpa diberikan intervensi pendidikan kesehatan didapatkan nilai z sebesar -4,571 dengan sebesar 0,000 dimana kurang dari batas kritis penelitian 0,05, berdasarkan nilai $p$-value maka keputusan uji adalah $\mathrm{H}_{0}$ ditolak, sehingga disimpulkan terdapat perbedaan pengetahuan bahaya seks bebas antara kelompok intervensi dan kelompok kontrol.

\section{HASIL PENELITIAN}

\section{Pengetahuan bahaya seks bebas sebelum pendidikan kesehatan pada kelompok intervensi}

Tabel 1. Distribusi Frekuensi Pengetahuan Bahaya Seks Bebas Pada Remaja Sebelum pendidikan Kesehatan Pada Remaja dengan Kelompok Intervensi

\begin{tabular}{ccc}
\hline Pengetahuan bahaya seks bebas & $\mathrm{n}$ & Persentase (\%) \\
\hline Baik & 1 & 3,3 \\
Cukup & 8 & 26,7 \\
Kurang & 21 & 70,0 \\
\hline
\end{tabular}

Berdasarkan tabel 1, bahwa pengetahuan bahaya seks bebas kelompok intervensi sebelum dilakukan pendidikan kesehatan pada remaja menunjukan kategori baik 1 orang (3,3\%), cukup 8 orang $(26,7 \%)$ dan kurang 21 orang $(70 \%)$.

\section{Pengetahuan bahaya seks bebas sesudah pendidikan kesehatan pada kelompok intervensi}

Tabel 2.Distribusi Frekuensi Pengetahuan Bahaya Seks Bebas Pada Remaja Sesudah Pendidikan Kesehatan Pada Remaja dengan Kelompok Intervensi

\begin{tabular}{lcc}
\hline \multicolumn{1}{c}{ Pengetahuan bahaya seks bebas } & $\mathrm{n}$ & Persentase (\%) \\
\hline Baik & 19 & 63,3 \\
Cukup & 10 & 33,4 \\
Kurang & 1 & 3,3 \\
\hline
\end{tabular}


Berdasarkan tabel 2, terlihat bahwa pengetahuan bahaya seks bebas pada kelompok intervensi sesudah dilakukan pendidikan kesehatan pada remaja menunjukan kategori baik yaitu 19 orang $(63,3 \%)$ dan kategori pengetahuan bahaya seks bebas cukup 10 orang $(33,4 \%)$ dan dengan kategori kurang 1 orang $(3,3 \%)$.

\section{Pengetahuan bahaya seks bebas sebelum pendidikan kesehatan pada kelompok kontrol}

Tabel 3. Distribusi Frekuensi Pengetahuan Bahaya Seks Bebas Pada Remaja Sebelum Pendidikan Kesehatan Pada Remaja dengan Kelompok Kontrol

\begin{tabular}{ccc}
\hline Pengetahuan bahaya seks bebas & $\mathrm{n}$ & Persentase (\%) \\
\hline Baik & 2 & 6,7 \\
Cukup & 13 & 43,3 \\
Kurang & 15 & 50,0 \\
\hline
\end{tabular}

Berdasarkan tabel 3, terlihat bahwa pengetahuan bahaya seks bebas pada kelompok kontrol sebelum pendidikan kesehatan pada remaja menunjukan bahwa kategori baik 2 orang $(6,7 \%)$, cukup 13 orang $(43,3 \%)$ serta dengan kategori kurang 15 orang $(50 \%)$.

\section{Pengetahuan bahaya seks bebas sesudah pendidikan kesehatan pada kelompok kontrol}

Tabel 4. Distribusi Frekuensi Pengetahuan Bahaya Seks Bebas Pada Sesudah Pendidikan Kesehatan Pada Remaja dengan Kelompok Kontrol

\begin{tabular}{ccc}
\hline Pengetahuan bahaya seks bebas & $\mathrm{n}$ & Persentase $(\%)$ \\
\hline Baik & 3 & 10,0 \\
Cukup & 16 & 53,3 \\
Kurang & 11 & 36,7 \\
\hline
\end{tabular}

Berdasarkan tabel 4, terlihat bahwa pengetahuan bahaya seks bebas sesudah pendidikan kesehatan pada remaja menunjukan bahwa kategori pengetahuan bahaya seks bebas dengan kategori baik 3 orang (10\%), cukup 16 orang(53,3\%), dan kurang11 orang (36,7\%).

\section{Perbedaan pengetahuan bahaya seks bebas pada remaja}

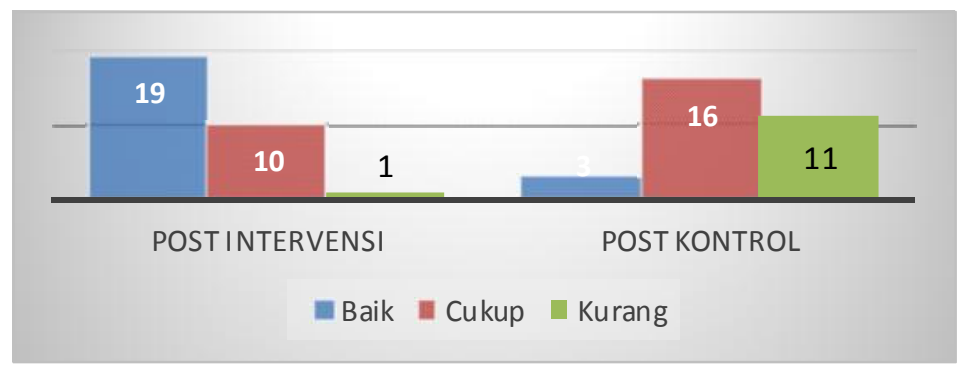

Gambar 1. Perbedaan pengetahuan bahaya seks bebas padaremaja pada kelompok intervensi dan kelompok kontrol

Berdasarkan gambar 1 menunjukkan bahwa adanya perbedaan pengetahuan bahaya seks bebas pada remaja antara kelompok intervensi dan kelompok kontrol pendidikan kesehatan pada remaja. Perbedaan pengetahuan bahaya seks bebas ini disebabkan karena adanya pendidikan kesehatan pada remaja yang dilakukan oleh responden.

Berdasarkan hasil post-test didapatkan hasil bahwa pengetahuan bahaya seks bebas pada remaja pada kelompok intervensi sesudah melakukan pendidikan kesehatan pada remaja dengan 
kategori pengetahuan bahaya seks bebas dengan kategori baik 19 orang (63,3\%), cukup 10 orang $(33,4 \%)$, dan kurang 1 orang $(3,3 \%)$. Sedangkan pada kelompok kontrol dengan kategori baik 3 orang (10\%), cukup 16 orang $(53,3 \%)$, dan kurang 11 orang $(36,7 \%)$.

Data diatas menunjukan bahwa perubahan yang signifikan terjadi kepada kelompok yang memang diberikan intervensi, dengan kata lain, kelompok yang tidak diberikan intervensi masih tergolong memiliki kemampuan atau pengetahuan tentang bahaya seks bebas yang kurang dan cukup.

\section{Pengaruh pendidikan kesehatan pada remaja terhadap perubahan pengetahuan bahaya seks bebas pada remaja}

Tabel 5. Nilai Pengaruh Pendidikan Kesehatan Pada Remaja Terhadap Perubahan Pengetahuan Bahaya Seks Bebas Pada Remaja

\begin{tabular}{|c|c|c|c|}
\hline Pengetahuan bahaya seks bebas & $\mathrm{Z}$ & Pvalue & $\mathrm{n}$ \\
\hline $\begin{array}{l}\text { Kelompok Intervensi Sesudah di Berikan Pendidikan } \\
\text { Kesehatan - Kelompok Intervensi Sebelum di Berikan } \\
\text { Pendidikan Kesehatan }\end{array}$ & $-4,802^{\mathrm{b}}$ & 0,000 & 30 \\
\hline $\begin{array}{l}\text { Kelompok Kontrol Sesudah di } \text { Berikan } \\
\text { Kesehatan - Kelompok Kontrol Sebelum di Berikan } \\
\text { Pendidikan Kesehatan }\end{array}$ & $-1,890^{b}$ & 0,059 & 30 \\
\hline
\end{tabular}

Hasil perhitungan nilai Wilcoxon Signed Rank Test Pada tabel 5 dengan kelompok intervensi didapatkan nilai z sebesar $-4,802$ dengan signifikansi sebesar 0,000 dimana kurang dari batas kritis penelitian 0,05. Berdasarkan nilai p-value maka keputusan uji adalah $\mathrm{H}_{0}$ ditolak, sehingga disimpulkan terdapat pengaruh pengetahuan bahaya seks bebas sebelum dan sesudah pendidikan kesehatan pada remaja. Sedangkan pada kelompok kontrol didapatkan nilai z sebesar 1.890 dengan signifikansi sebesar 0,059 dimana lebih dari batas kritis penelitian 0,05. Berdasarkan nilai $p$-value maka keputusan uji adalah $\mathrm{H}_{0}$ ditolak, sehingga disimpulkan tidak terdapat pengaruh pengetahuan bahaya seks bebas sebelum dan sesudah pendidikan kesehatan pada remajaterhadap pengetahuan bahaya seks bebas pada remaja.

Tabel 6. Nilai Pengaruh Pendidikan Kesehatan Pada Remaja Terhadap Perubahan Pengetahuan Bahaya Seks Bebas Pada Remaja

\begin{tabular}{|c|c|c|c|}
\hline Pengetahuan bahaya seks bebas & $\mathrm{Z}$ & Pvalue & $\mathrm{n}$ \\
\hline $\begin{array}{l}\text { Kelompok Intervensi Sesudah di Berikan Pendidikan } \\
\text { Kesehatan - Kelompok Kontrol Sesudah di Berikan } \\
\text { Pendidikan Kesehatan }\end{array}$ & $-4,571$ & 0,000 & 60 \\
\hline
\end{tabular}

Hasil perhitungan nilai Man Whitney Test ada tabel 6 dengan kelompok intervensi sesudah diberikan pendidikan kesehatan dan kelompok kontrol tanpa diberikan intervensi pendidikan kesehatan didapatkan nilai z sebesar -4,571 dengan sebesar 0,000 dimana kurang dari batas kritis penelitian 0,05. Berdasarkan nilai p-value maka keputusan uji adalah $\mathrm{H}_{0}$ ditolak, sehingga disimpulkan terdapat perbedaan pengetahuan bahaya seks bebas antara kelompok intervensi dan kelompok kontrol. Hasil uji statistik tersebut menunjukan bahwa terdapat perbedaan yang signifikan setelah dilakukan pendidikan kesehatan pada remaja terhadap pengetahuan bahaya seks bebas pada remaja. 


\section{PEMBAHASAN}

\section{Pengetahuan bahaya seks bebas sebelum melakukan pendidikan kesehatan pada remaja pada kelompok intervensi dan kelompok kontrol}

Hasil penelitian menunjukan bahwa pengetahuan bahaya seks bebas pada responden remaja dengan kelompok intervensi sebelum diberikan pendidikan kesehatan pada remaja menunjukan dengan kategori baik, yaitu 1 orang $(3,3 \%)$, cukup 8 orang $(26,7 \%)$, dan kurang 21 orang $(70 \%)$. Sedangkan data pada kelompok kontrol didapatkan dengan kategori baik yaitu 2 orang $(6,7 \%)$, cukup 13 orang $(43,3 \%)$, dan kurang 15 orang $(50 \%)$.

Seks bebas diartikan sebagai perilaku yang didorong oleh hasrat seksual, dimana kebutuhan tersebut menjadi lebih bebas jika dibandingkan dengan sistem regulasi tradisional dan bertentangan dengan sistem norma yang berlaku dalam masyarakat. ${ }^{16}$ Senada dengan pernyataan Desmita (2005) pengertian seks bebas merupakan segala cara mengekspresikan dan melepaskan dorongan seksual yang berasal dari kematangan organ seksual, seperti berkencan intim, bercumbu, sampai melakukan kontak seksual, tetapi perilaku tersebut dinilai tidak sesuai dengan norma karena remaja belum memiliki pengalaman tentang seksual. ${ }^{17}$

Berdasarkan pendapat diatas, peneliti dapat menginterpretasikan bahwa seks bebas adalah berhubungan intim yang didorong oleh hasrat seksual, dengan cara mengekpresikan hasrat seksual, dengan bercumbu, berkencan intim sampai melakukan hubungan intim tanpa adanya hubungan pernikahan dan dianggap tidak sesuai dengan norma yang berlaku di masyarakat. Hal tersebut terjadi bisa dikarenakan oleh minimnya pengetahuan yang dimiliki oleh individu.

Pengetahuan merupakan suatu hasil dari "tahu" dan ini terjadi setelah melakukan pengindraan terhadap suatu objek tertentu. ${ }^{15}$ Perilaku yang didasari oleh pengetahuan akan lebih langgeng dari pada perilaku yang tidak didasari oleh pengetahuan. Penelitian Rogers mengungkapkan bahwa sebelum orang mengadopsi perilaku baru (berperilaku baru) didalam diri orang tersebut terjadi proses yang berurutan, yakni: ${ }^{15}$ Pertama adalah awareness (kesadaran), dimana pada tahapan ini orang mulai menyadari dalam arti mengetahui stimulasi (objek) terlebih dahulu. Kedua adalah interest, pada tahap ini biasanya orang mulai tertarik kepada stimulus. Ketiga adalah evaluation dalam tahapan ini biasanya seseorang mulai (menimbang-nimbang terhadap baik dan tidaknya stimulus tersebut bagi dirinya. Hal ini berarti sikap responden sudah lebih baik lagi. Keempat adalah trial, tahapan ini biasanya orang telah mulai mencoba perilaku baru. Kelima adalah adaptation, tahapan ini biasanya ditndai dengan subjek yang telah berperilaku baru sesuai dengan pengetahuan, kesadaran dan sikapnya terhadap stimulus.

Selain itu, pengetahuan juga dibagi menjadi beberapa tingkatan yang harus dimiliki oleh masing-masing individu, yaitu diawali dengan tahu (know), know disini didefinisikan sebagai suatu hal untuk mengingat kembali (recall) sesuatu yang sangat spesifik dari seluruh bahan yang dipelajari atau rangsangan yang telah diterima. Kemudian dilanjutkan dengan proses memahami (comprehensif) ini teridiri dari kemampuan untuk menjelaskan secara benar tentang objek yang diketahui, dan dapat menginterpretasikan materi tersebut secara benar. Orang yang telah paham terhadap objek atau materi harus dapat menjelaskan dan menyebutkan. Selanjutnya yaitu aplikasi (application) diartikan sebagai kemampuan untuk menggunakan materi yang telah dipelajari pada suatu kondisi real (sebenarnya). Aplikasi disini dapat diartikan sebagai aplikasi atau penggunaan hukum-hukum, rumus, metode, prinsip dan sebagainya dalam konteks atau situasi yang lainya. Tingkatan berikutnya yaitu analisis (analysis) adalah suatu kemampuan untuk menjabarkan materi atau suatu objek kedalam komponen-komponen, tetapi masih di dalam satu struktur dan organiasi dan masih ada kaitannya satu sama lain. Berikutnya adalah tingkat sintesis (synthesis) adalah suatu kemampuan untuk menyusun formulasi baru dari formulasi-formulasi yang ada. Misalnya dapat menyusun, dapat merencanakan. Dapat meringankan, dan menyesuaikan dan sebagainya terhadap suatu teori atau rumusan-rumusan yang telah ada. Terakhir adalah evaluasi (evaluation), evaluasi ini berkaitan dengan kemampuan untuk melakukan justifikasi/penilaian terhadap suatu materi atau objek. Penilaian-penilaian itu didasarkan pada suatu kriteria yang ditentukan sendiri atau mengunakan kriteria yang sudah ada.

Sejalan dengan pernyataan di atas, penting untuk diperhatikan oleh semua individu, 
khususnya oleh para remaja dan umumnya oleh semua usia, bahwa penyelenggaraan pendidikan kesehatan dapat meminimalisir dan mencegah perilaku yang mengarah kepada pergaulan bebas atau seks bebas.

\section{Pengetahuan bahaya seks bebas sesudah melakukan pendidikan kesehatan pada remaja pada kelompok intervensi dan kelompok kontrol}

Hasil penelitian sesudah dilakukan intervensi didapatkan bahwa pengetahuan bahaya seks bebas pada responden remaja sesudah pelaksanaan pendidikan kesehatan pada remaja denga kelompok intervensi menunjukan bahwa kategori pengetahuan bahaya seks bebas dengan kategori baik yaitu 19 orang $(63,3 \%)$, cukup 10 orang $(33,4 \%)$, dan kurang 1 orang $(3,3 \%)$. Sedangkan pada kelompok kontrol didapatkan hasil penelitian dengan kategori baik yaitu 3 orang (10\%),cukup16 orang $(53,3 \%)$, dan kurang 11 orang $(36,7 \%)$.

Perilaku seks bebas pada remaja adalah cara remaja mengekspresikan dan melepaskan dorongan seksual, yang berasal dari kematangan organ seksual dan perubahan hormonal dalam berbagai bentuk tingkah laku seksual. Tetapi perilaku tersebut dinilai tidak sesuai dengan norma karena remaja belum memiliki pengalaman tentang seksual. ${ }^{18}$ Faktor-faktor penyebab masalah seks bebas pada remajadari berbagai hasil studi tentang masalah seksualitas pada remaja yang menyebabkan mereka melakukan seks bebas antara lain yaitu: ${ }^{2}$ Perubahan-perubahan hormonal yang meningkatkan hasrat seksual (libido seksualitas) remaja. Peningkatan hasrat seksual ini membutuhkan penyaluran dalam bentuk tingkah laku seksual tertentu. Kemudian penyaluran tersebut tidak dapat segera dilakukan karena adanya penundaan usia perkawinan, baik secara hukum karena adanya undang-undang tentang perkawinan yang menetapkan batasan usia nikah (sedikitnya usia 16 tahun untuk wanita dan 19 tahun untuk pria), maupun karena norma sosial yang makin lama makin menuntut persyaratan yang semakin tinggi untuk perkawinan (pendidikan, pekerjaan, persiapan mental, dan lain-lain). Tidak hanya itu, kecenderungan pelanggaran makin semakin meningkat oleh karena adanya penyebaran informasi dan rangsangan seksual melalui media massa yang dengan adanya teknologi canggih (video CD, Foto Copy, Satelit, VCD, handphone, internet dan lain-lain). Menjadi tidak terbendung lagi. Remaja yang sedang dalam periode ingin tahu dan ingin mencoba, akan meniru apa yang dilihat atau didengarnya dari media massa, khususnya karena mereka pada umumnya belum pernah mengetahui masalah seksual secara lengkap dari orangtuanya.Orang tua sendiri, baik karena ketidaktauannya maupun karena sikapnya yang masih mentabukan pembicaraan mengenai seks dengan anak tidak terbuka terhadap anak, malah cenderung membuat jarak dengan anak dalam masalah yang satu ini.

Hal tersebut menjadi dasar bahwa semakin besar kemungkinan seorang remaja untuk terpapar dengan perilaku seks bebas karena berbagai macam alasan. Oleh karena itu pengetahuan mengenai seks bebas serta dampak dari seks bebas penting untuk diketahui oleh anak remaja supaya bisa meminimalisir angka kejadian pergaulan bebas. Adapun cara yang bisa dilakukan yaitu dengan berbagi pengalaman, tingkat pendidikan, tingkat keyakinan, fasilitas, penghasilan dan sosial budaya. Salah satu contohnya yaitu berdasarkan pengalaman, dengan berbagi pengalaman, maka apa yang pernah dan sedang kita ataupun orang lain lakukan ikut membentuk dan mempengaruhi penghayatan kita terhadap stimulus tanggapan akan menjadi salah satu dasar terbentuknya pengetahuan dan sikap.

\section{Pengaruh pendidikan kesehatan pada remaja terhadap perubahan pengetahuan bahaya seks bebas pada remaja.}

Hasil perhitungan nilai Wilcoxon Signed Rank Test Pada tabel 5 pada kelompok intervensi didapatkan nilai z sebesar -4,802 dengan signifikansi sebesar 0,000 dimana kurang dari batas kritis penelitian 0,05. Berdasarkan nilai $p$-value maka keputusan uji adalah $\mathrm{H}_{0}$ ditolak, sehingga disimpulkan terdapat pengaruh pengetahuan bahaya seks bebas sebelum dan sesudah pendidikan kesehatan pada remaja terhadap pengetahuan bahaya seks bebas pada remaja.

Sedangkan Hasil perhitungan nilai Wilcoxon Signed Rank Test Pada tabel 5 dengan kelompok kontrol didapatkan nilai z sebesar -1.890 dengan signifikansi sebesar 0,059 dimana lebih 
dari batas kritis penelitian 0,05. Berdasarkan nilai p-value maka keputusan uji adalah $\mathrm{H}_{0}$ ditolak, sehingga disimpulkan tidak terdapat pengaruh pengetahuan bahaya seks bebas sebelum dan sesudah pendidikan kesehatan pada remaja terhadap pengetahuan bahaya seks bebas pada remaja.

Kemudian untuk hasil perhitungan nilai Man Whitney Test ada tabel 6 pada kelompok intervensi sesudah diberikan pendidikan kesehatan dan kelompok kontorl tanpa diberikan intervensi pendidikan kesehatan didapatkan nilai z sebesar -4,571 dengan signifikansi sebesar 0,000 dimana kurang dari batas kritis penelitian 0,05. Berdasarkan nilai p-value maka keputusan uji adalah $\mathrm{H}_{0}$ ditolak, sehingga disimpulkan terdapat perbedaan pengetahuan bahaya seks bebas antara kelompok intervensi dan kelompok kontrol. Hasil uji statistik tersebut menunjukan bahwa terdapat perbedaan yang signifikan setelah dilakukan pendidikan kesehatan pada remaja terhadap pengetahuan bahaya seks bebas pada remaja.

Pendidikan secara umum adalah segala upaya yang direncanakan untuk mempengaruhi orang lain baik individu, kelompok atau masyarakat sehingga mereka melakukan apa yang dilakukan oleh pelaku pendidikan. Dari batasan ini tersirat unsur-unsur pendidikan yakni; input adalah sasaran pendidikan (individu, kelompok, masyarakat) dan pendidik (pelaku pendidikan), proses (upaya yang direncanakan untuk mempengaruhi orang lain), output (melakukan apa yang diharapkan atau perilaku). ${ }^{19}$

Kesehatan merupakan hasil interaksi dari berbagai faktor, baik faktor internal (dari dalam diri manusia) maupun faktor eksternal (diluar disi manusia). Faktor internal ini terdiri dari faktor fisik dan psikis. Faktor eksternal terdiri dari beberapa faktor antara lain; sosial, budaya, masyarakat, lingkungan fisik, politik, ekonomi, pendidikan, dan sebagainya. ${ }^{11}$ Sedangkan pendidikan kesehatan adalah aplikasi atau penerapan pendidikan didalam bidang kesehatan. Secara operasional pendidikan kesehatan adalah semua kegiatan untuk memberikan dan atau meningkatkan pengetahuan, sikap, dan praktek baik individu, kelompok atau masyarakat dalam memelihara dan meningkatkan kesehatan mereka sendiri. ${ }^{19}$ Sehingga pendidikan kesehatan dapat didefinisikan sebagai suatu proses atau upaya untuk mempengaruhi orang lain baik individu, kelompok atau masyarakat berprilaku sesuai dengan nilai-nilai kesehatan. ${ }^{20}$

Tujuan dilaksanakan pendidikan kesehatan yaitu untuk merubah perilaku individu atau masyarakat dibidang kesehatan. Tujuan ini dapat diperinci menjadi: ${ }^{19}$ Pertama menjadikan kesehatan menjadi suatu yang bernilai di masyarakat, menolong individu agar mampu secara mandiri atau berekelompok mengadakan kegiatan untuk mencapai tujuan hidup sehat, mendorong perkembangan dan penggunaan secara tepat sarana pelayanan kesehatan yang ada.

Hasil penelitian Dwi Setiowati pada tahun (2014), dengan jumlah sampel penelitian 160 siswi bahwa terdapat pengaruh pendidikan kesehatan reproduksi terhadap peningkatan pengetahuan remaja di SMKN Islam Wijaya Kusuma Jakarta Selatan. Sebelum diberikan pendidikan kesehatan reproduksi tentang seks bebas yang tergolong kategori baik sebesar 5,6\%, kategori cukup 82,5\%, dan kategori kurang sebesar $11,9 \%$. Setelah dilakukan pendidikan kesehatan reproduksi tentang seks bebas yaitu tergolong kategori baik sebesar 42,5\%, kategori cukup sebesar 56,3\%, dan kategori kurang sebesar $1,3 \% .^{21}$

Hasil penelitian Dian Savitri, Kirnantoro, dan Siti Nurunniyah (2013), dengan jumlah sampel yang digunakan 43 siswa, jenis penelitian praeksperimenone group pretest posttest, hasil penelitian menunjukkan tingkat pengetahuan responden sebelum intervensi adalah tinggi sebanyak 27 responden $(62,8 \%)$, sedangkan sebanyak 10 responden $(23,3 \%)$ dan rendah sebanyak 6 responden (14\%). Tingkat pengetahuan responden setelah intervensi adalah tinggi sebanyak 35 responden $(81,4 \%)$, sedangkan sebanyak 8 responden $(18,6 \%)$ dan rendah $(0 \%)$. Dan hasil penelitian menunjukkan ada pengaruh yang signifikan antara pemberian pendidikan kesehatan reproduksi terhadap tingkat pengetahuan tentang seks bebas pada remaja. ${ }^{22}$

Melalui pendidikan kesehatan ini telah terbukti bahwa dapat meningkatkan pengetahuan siswi tentang bahaya seks bebas, yang bertujuan untuk pencegahan terjadinya seks bebas di kalangan siswi. 


\section{SIMPULAN}

Pengetahuan bahaya seks bebas pada responden remaja pada kelompok intervensi sebelum pendidikan kesehatan pada remaja menunjukan kategori baik yaitu 1 orang (3,3\%), cukup 8 orang (26,7\%), dan kurang 21 orang (70\%). Sedangkan data sesudah diberikan intervensi pendidikan kesehatan pada remaja didapatkan hasil dengan kategori baik yaitu 19 orang $(63,3 \%)$, cukup 10 orang $(33,4 \%)$, dan kurang yaitu 1 orang $(3,3 \%)$.

Pengetahuan bahaya seks bebas pada responden remaja pada kelompok kontrol sebelum didapatkan hasil dengan kategori baik yaitu 2 orang (6,7\%), cukup 13 orang (43,3\%), dan kurang 15 orang $(50 \%)$. Sedangkan data sesudah didapatkan hasil data dengan kategori baik yaitu 3 orang (10\%), cukup16 orang (53,3\%), dan kurang 11 orang $(36,7 \%)$.

Hasil perhitungan nilai Man Whitney Test dengan kelompok intervensi sesudah diberikan pendidikan kesehatan dan kelompok kontrol tanpa diberikan intervensi pendidikan kesehatan didapatkan nilai signifikansi sebesar $0,000(<0,05)$, sehingga terdapat perbedaan pengetahuan bahaya seks bebas antara kelompok intervensi dan kelompok kontrol. Hasil uji statistik tersebut menunjukan bahwa terdapat perbedaan yang signifikan setelah dilakukan pendidikan kesehatan pada remaja terhadap pengetahuan bahaya seks bebas pada remaja.

\section{SARAN}

Menjadi masukan bagi responden tentang bagaimana cara melakukan pendidikan kesehatan pada remaja dan mendapatkan pengetahuan bahaya seks bebas sehingga dapat meminimalisir angka seks bebas. Sedangkan saran untuk peneliti berikutnya dapat dilakukan penelitian pada responden yang berbeda, dengan jumlah sampel yang lebih besar dan waktu penelitian yang lebih panjang, tambahan literature mengenai metode, teknik dan pelaksanaan untuk lebih mendukung dan memperkuat hasil penelitian.

\section{DAFTAR PUSTAKA}

1. Koes Irianto. Seksiologi kesehatan. Bandung: Alfabeta; 2014.

2. Sarlito W.Sarwono. Psikologi remaja.Jakarta: Raja Grafindo Persada; 2018.

3. VOA. Dewan HAM PBB Siap bahas resolusi tentang perkawinan anak; 2017 [diakses pada tanggal 13 februari 2019]. Tersedia dari: https://www.voaindonesia.com.

4. Kemdikbud. Statistik pendidikan; 2018 [diakses tanggal 10 februari 2019]. Tersedia dari: http://statistik.data.kemdikbud.go.id.

5. OkeZone.com. Pernikahan dini di Indramayu 2014-2016 ; 2016 [diakses pada 12 februari 2019]. Tersedia dari: https://news.okezone.com.

6. TribunNews.com. Pernikahan dini Indramayu 2016-2017; 23 November 2018 [diakses pada tanggal 12 februari 2019]. Tersedia dari http://bali.tribunnews.com.

7. Natalia, K,P. Gambaran pengetahuan, sikap dan perilaku siswa- siswi SMA X Kota Bandung terhadap seks bebas dari infeksi menular seksual tahun 2014 (Skripsi); 2014.

8. Fitra, I.A. Konsep diri remaja putri dalam menghadapi menarche.UIN Sunan Ampel; 2014.

9. Fitriani, S. Promosi Kesehatan. Yogyakarta: Graha Ilmu; 2011.

10. Atiek Novianty, Benny Hasan Purwara, Sari Puspa Dewi, Farid Husin, Tuti Wahmurti, Irvan Afriandi. Journal pengaruh pendidikan kesehatan reproduksi remaja terintegrasi terhadap peningkatan kontrol diri di Kabupaten Indramayu; 2015.

11. Muhammad Hamka, H. Jamaluddin Hos, Megawati A. Tawalo. Jurnal perilaku seks bebas di kalangan remaja; 2015.

12. Fitriani, S. Promosi kesehatan. Yogyakarta. Graha Ilmu; 2011.

13. Herry Setiawan, dkk. Analisa peran perawat dalam promosikesehatan. [diakses pada tanggal 15 Februari 2019]. Tersedia darihttps://www.academia.edu; 2014.

14. Nursalam. Kosep dan penerapan metodologi penelitian ilmu keperawatan. Pedoman Skripsi Tesis Dan Instrumen Penelitian Keperawatan Edisi 2. Jakarta: Salemba Medika; 2008.

15. Notoatmodjo, S. Promosi Kesehatan dan Ilmu Perilaku. Jakarta: Rineka Cipta; 2007. 
16. Psychologymania. Pengertian seks bebas; 1 juni 2012; 2012 [diakses pada tanggal 20 februari 2019]. Tersedia dari https://www.psychologymania.com.

17. Muhammad Hamka, H. Jamaluddin Hos, Megawati A. Tawalo; 2016. Journal perilaku seks bebas di kalangan remaja.

18. Notoatmodjo, S. Promosi kesehatan dan ilmu perilaku. Jakarta: Rineka Cipta; 2007.

19. Fitriani, S. Promosi kesehatan. Yogyakarta. Graha Ilmu; 2011.

20. Ali, Zaidin. Dasar-dasar pendidikan kesehatan masyarakat dan promosi kesehatan. Jakarta: Trans Info Media; 2010.

21. Dian Savitri, Kimantoro, dan Siti Nurunniyah. Jurnal Pemberian pendidikan kesehatan reproduksi berpengaruh terhadap tingkat pengetahuan tentang seks bebas pada remaja kelas $\mathrm{X}$ dan XI di SMK Muhammadiyah II Bantul; 2013.

22. Nursalam. Metodologi penelitian ilmu keperawatan pendekatan praktis edisi 3. Jakarta: Salemba Medika; 2013. 